\title{
Zene, tánc és rítus az Andokban (Letenyei László)
}

Eredetileg megjelent: Gelencsér Ágnes, Letenyei László és Takács Ildikó 1994: Indián énekeskönyv. Budapest: Calibra.

\section{Zene és tánc}

A spanyol hódítás elôtt az andesi indiánok a zenei hangot mint a hangszerekbốl kiszálló démont, tisztelettel övezték. Bár a zenei harmónia jótékony hatását jól ismerték, a hang keletkezésére nem tudtak magyarázatot adni. Feltételezték, hogy a hang varázslatának nagy hatalma van: ezért kaptak fontos szerepet bizonyos hangszerek a gyógyászatban, és Poma de Ayala krónikájának bizonysága szerint fegyverekkel és hangszerekkel, csengókkel szálltak szembe a parasztok a jégesốvel is. Az ütközetek alatt különleges kürtök, sípok szóltak, amelyektôl azt remélték a harcosok, hogy a hangjuk megfutamítja az ellenséget.

A zene hatalmában való hit egyik oka az lehetett, hogy az írást nem ismerố indián társadalomban különösen fontos volt a szóbeli hagyomány pontos felidézése és továbbadása. A pontos emlékezést segítette a versbe szedett szövegek ritmusa, ríme, és még inkább a dallama, amely így fontos információhordozó is volt. Természetes, hogy a szent szövegek zenéjének éppúgy kijárt a tisztelet, mint az Óvilágban a szent könyveknek.

A dallamokat az énekhangon kívül fúvós, csörgô- és ütôhangszerek szólaltatták meg. Kolombusz elôtt a húros hangszereket egyáltalán nem ismerték. A zeneszerszámok használatát a vallás és a hagyomány szabályozta. Az ünnepi naptár bizonyos idôszakaihoz 
meghatározott hangszerek illettek, s minden ünnepnek megvolt a maga különleges hangszere is; a legtöbb ezért csak egyszer került eló egy évben. Általában csupán három hangszert: a pánsípot, a furulyát és a dobot használták; ezeknek viszont roppant változatos formáit ismerték, és használják ma is.

A pánsípok közül a legkisebb alig néhány centis, a legnagyobb fajta pedig hat méter hosszú. Van négy, és huszonnégy sípos egyaránt. Legismertebb közülük a manta, spanyolul zampona, amelyet ma már tizenöt síppal, teljes hangsorral készítenek. A rondadort Ecuadorban használják, és jellegzetessége, hogy egyszerre két sípot lehet rajta megszólaltatni. A két síp szép összhangzatot ad. A puntutu szintén pánsíp, amely embermagasságú, vagy annál hosszabb csöveket tartalmaz, és nagyon mély hangja van. A furulyák közül a ken a legismertebb, amely teljes hangsorú skála lejátszására alkalmas, három oktávban.

A mancsaj ppujlut, más néven tullyu kenôt emberi vagy állati lábszárcsontból faragják. Kettô vagy három lyukkal látják el, hangja egészen panaszos, bánatos. Még a XVI. században is használták mint diadalmi harci sípot. A csaták végeztével a legyôzöttek testéból készítették, s egy emberi lábat faragtak rá, azt fejezve ki ezzel, hogy így tapossa el a gyôztes a legyőzötteket.

A hangszer készítését valószínúleg már az Inkák is betiltották, ezért ma már alig használják. Az Inkák ehelyett az ellenség bóréból készítették a runatina nevú dobot, amely a krónikások leírásai szerint úgy nézett ki, mintha az áldozat még élne. A dob hasa az elesett ellenség hasa volt.

Ma már nagyon nehéz feladat lenne megállapítani, hogy milyen lehetett a térség zenéje a spanyolok bejövetele elôtt. A hódítást követô néhány évtized alatt megszúnt az inka udvari múvészet, és nem maradt ránk a nagy járványok és a népirtás terhét leginkább viselő tengerparti lakosság népzenéje sem. Csupán a hegyvidék falvainak zenéje élte túl ezt a korszakot. Ez a muzsika pentaton, és hagyományosan négysoros, ütemes verselésú dalok íródnak rá. 
José Portugal-Catacora ezt a népdalkincset saját kifejezései szerint geodemográfiai, történeti és kulturális-társadalmi hovatartozás szerint jellemzi. Geodemográfiai szempontból északi, azaz kecsua, és déli, aymara indián népzenét különböztet meg. A két zenevilág határa szerinte a Peru és Bolívia határa körül húzódó etnikai határ. Történeti szempontból a Kolombusz elốtti és utáni korszakot tartja alapvetốen különbözônek, kulturális hovatartozás szerint pedig indián és mesztic zenérôl beszél.

A geodemográfiai különbség megértéséhez hangsúlyozni kell, hogy az Andok északi és déli területei közt milyen nagyok az éghajlati különbségek. Az egyenlítôi Ecuadortól dél felé haladva az éghajlat fokozatosan húvösebb és szárazabb lesz, és a táj is ennek megfelelôen mind kopárabb, kietlenebb. Míg Ecuador földjét buja növényzet borítja a télen-nyáron $25-30^{\circ} \mathrm{C}$ körüli, párás éghajlat alatt, addig Peruban az éghajlat már jóval húvösebb, a növényzet gyérebb, és Bolívia térségében már csupaszon emelkednek az ég felé a gigantikus hegycsúcsok. Szürke vagy vörös kôtestük óriási méretei inkább istenek, mint az emberek léptékéhez illik. Ugyanez a különbség mutatkozik a népzenében is: az ecuadori népzene még akkor is pergó és ütemes, ha épp egy szomorú témáról vall. A dallamok általában egyszerúek, a négysoros énekek gyakran ugyanazt a hangsort ismétlik négyszer egymás után.

Délen az Andok hegyláncai szétnyílnak, dél-keleti és dél-nyugati irányba futnak tovább. Középen helyet hagynak az Altiplanónak, a Magasföldnek. Szentnek tartott föld ez. Sehol sem laknak emberek olyan közel az éghez, mint itt. Ehhez méltóan a déli ember népzenéje mindig ünnepélyes és fenséges; még ha egy gyors, harci vagy ünnepi ritmust játszanak is, a zene nem nélkülözheti a kimértséget, a szöveg pedig a megfontoltságot. Az énekek jelentôs részére, akár a régi magyar népzenére, az ereszkedố hangsorú dallam a jellemzô.

A spanyol hódítás és az európai kultúrával való érintkezés a népzenei életben is nagy változásokat hozott. A hódítók a gyarmatosítás elsố idôszakában alig törôdtek a spanyol nyelv és a zene terjesztésé- 
vel, a lakosság leigázását és gazdasági kizsákmányolását fontosabbnak tartották. Az inka kultúra nagyszerú alkotásai nem nyúgözték le ôket. Barbároknak tekintették az indiánokat, és küldetésüknek érezték, hogy túzzel-vassal terjesszék közöttük a kereszténységet és az európai kultúrát. Kezdetben a spanyol gyarmati jog semmi védelmet nem biztosított a hódítók túlkapásaival és a vallási fanatizmussal szemben. Az inkvizíció már azért is elítélhetett valakit, mert nem a „keresztény” spanyolt, hanem „pogány” anyanyelvét beszélte. Néhány évtized elég volt ahhoz, hogy az Inkák vallási kegyhelyeit lerombolják, a papságot elüldözzék, likvidálják a csomóírás szakértóit, azaz a hivatalnokokat. A korszak alatt elpusztult az inka színjátszás, az udvari költészet és zene. Csupán a parasztok népzenéje ôrizte meg e fenséges múvészet elemeit.

Késôbb, a katolikus vallás terjedésével egyidejúleg, és részben az egyházi zene hatására, a két zenei világ mindinkább közelíteni kezdett egymás felé. Idôvel a spanyol húros hangszerek is ismertté váltak az indiánok között; a gitáron kívül délen inkább a tatu páncéljából készített csarangót, északon a mandolint használják ma is szívesen.

A spanyol hódítók és az indián ôslakók ötvözôdésébôl született mesztic lakosság népi muzsikája az andokbeli népzene újabb rétege.

Az indián népzene hangszereit nem lehetett akármikor, akárhol elôvenni: a vallási törvények és a hagyományok szigorúan meghatározták, hogy melyik hangszeren az év melyik szakában, mely rítus keretében lehetett játszani. A mesztic népzene már nem ôrzi ezeket a hagyományokat. Lényegesen kevesebb, ám sokoldalúbb hangszert használ, amelyek, ha indián eredetűek is, alkalmasak a teljes skála játszására. Módosult a dallamvilág is. A kialakuló mesztic zene nyelve lassanként a spanyol lett.

Azok az együttesek, amelyek Európa-szerte, így Magyarországon is andokbeli népzenét szoktak játszani, ilyen értelemben mesztic zenei együttesek. A dallamvilág módosulása és a nyelvváltás folyamata nem zárult le. Az ôsi dallamoknak mind újabb és újabb változatai születnek ma is a népszerú mesztic együttesek feldolgozásában. 


\section{Tánc és rítus}

Az Andokban a dal nem egyszerúen ének, hanem a költészet legkézenfekvốbb formája is. A tánc nem csupán tánc, de az emberi kapcsolatteremtés egyik legfontosabb fóruma. A magas hegyek indiánja zárkózott és hallgatag. Ha valamiról vallania kell, nem szívesen beszél róla, hanem inkább eltáncolja. Eltáncolja, hogy mi történt vele, mi történt népével, mi áll vallásában, mit hisz és képzel a világról; mozgásával vall szerelmet választottjának, mozdulataival beszél magáról.

Kolombusz elốtt az indiánok nem tudtak írni-olvasni, nem ismerték a vasárnapot, a rendszeres templomba járás, igehirdetés és tájékoztatás rendszerét. Viszont elég gyakran - Garcilaso de Vega szerint körülbelül kilencnaponta - tartottak egy-két napos vallásos szertartásokat. Ezek az ünnepek jelentették a misét, ez volt a történelemóra, és itt kaptak hírt a világról.

A híradó mindig dramatizálva folyt. Ennek emlékei a ma is éló chiriguano és tobas nevú táncok, amelyek a hegyvidéki indiánok és az ôserdei törzsek harcait játsszák újra. A tánc során a férfiak egy része ôserdei indiánnak öltözik (vagyis vetkôzik), s a tánc közben legyốzetik. Az ilyen jellegú táncok jelentették e falvak történetírását, s azt jelentik még ma is, hisz a táncokat, melyek hat-hétszáz évvel ezelôtt zajlott háborúkra utalnak, még ma is járják Bolíviában, Oruro vidékén.

A vallásos szertartások táncai mozgásukkal, a viseletek színeivel, formájával erôsítik az emberekben a vallásos világképet. A szertartások koreográfiája meghatározza a férfiak és nôk, gyermekek és öregek helyét, mintegy földi másaként a mennyek elrendezôdésének. Az aktív táncos részvétel a hívôktôl teljes odaadást és azonosulást követelt meg, és teremtett. Ilyen tánc volt a tinku szertartáshoz kötődố jula juta, vagy a huaynu ôse, a k'aswa is.

A mindennapi élet, a munka bemutatására, illetve a fiatalok nevelésére és oktatására is születtek munkatáncok. A llamerada a lámapásztorok tánca, a huaylas a földmúveseké. Az ilyen jellegú táncok 
a munka megszokott mozdulatait emelik múvészi szintûre. Ez a jelenség a magyar népi hagyományokban sem ismeretlen, gondoljunk például a csưrdöngölốre, amely a padló döngölésének mozdulatait idézi. Az Inkakorban minden mezei munkát táncos mezei felvonulással kezdtek a falvak, ahol zeneszó mellett eljátszották a munka menetét: a föld felásását, a magok elvetését, a betakarítást. E színjátékkal a Földanya, Pachamama kegyeit akarták elnyerni. A dolgos szertartásokat, melyeket az egész birodalomban egy napon tartottak, mindig az uralkodó kezdte meg. A vigadalmak, mulatságok táncai is e forrásokból táplálkoztak. Így például egy falusi lakodalomban nyilván a termékenységet és jó termést kérô és jelentố vallásos táncokat járták, illetve olyan munkatáncokat, amelyek illettek a család foglalkozásához. A spanyol hódítás késôbb fokozatosan megváltoztatta az indiánok vallással és az Inkák világi kormányzatával átszôtt világát.

A gyarmati rend megszilárdulásáig a falvak életének rendes menete alig változott, s ezért a hagyományos népzene is változatlan formában élt tovább. A spanyolok hatása elôször érdekes módon az indián harci szertartásokhoz kötôdố táncokban jelentkezett. Ma is számos olyan táncot ismerünk, amelynek az a csattanója, hogy az indiánok eljátsszák és kifigurázzák a spanyolok szokásait, öltözékét. Ilyen tánc például a chunguinada.

Szomorú, lassú zene és tánc az ayarachi, melyet Peruban, Candelaría del Punoban járnak. A történet szerint a kegyetlen spanyolok által Cuzcóból elüldözött Inka nemesek a Paratia havas bércei közé menekültek, s sorsuk kegyetlen fordulatára emlékezôn született táborukban ez a dal, majd késôbb a nép ajkán a népzene és a tánc.

Az Andokban addig ismeretlen háziállatokat, fôleg a szamarat és a tehenet az indiánok hamar hasznosították. Természetesen róluk is szólnak munkadalok és táncok. A waca-waca a tehenek és ökrök nehézkes, döcögốs járását utánozza.

A hódítást követố évszázadok alatt a konkvisztádorok leszármazottai mind élesebben elhatárolták magukat spanyolországi honfitársaiktól, s egyidejúleg megindult a bennszülöttek és a fehérek 
kulturális és fizikai keveredése. A meszticizálódás ma már nagyon előrehaladott folyamat Dél-Amerikában. Ezzel egyidejúleg túnik el szemünk elốl a régi indián zenéhez és tánchoz kötôdố vallás és hiedelemvilág. Igaz, a táncok még ma is sok mozgáson kívüli elemet tartalmaznak: nagyon fontos a maskarák, viseletek szerepe, a színeké és a szövetmintáké. Sok népi táncnak van pontos, színpadra kívánkozó koreográfiája. Épp a legfontosabb szertartásokhoz kötôdô táncritmusok hagyományai viszont erốteljes egyházi felügyelet miatt már nem épülhettek be a mesztic világképbe. Így járt a tinku és a huaynu is.

Jó pár táncot ismerünk azonban, amely a vallási kettôsség, a katolikus hit és a régi indián vallás együttélésének legékesebb bizonyítékai. Ezek fớleg úgy alakultak ki, hogy az ôsi indián ünnepeket jószándékú misszionáriusok keresztény ünneppé próbálták átformázni. Jó példa erre az ecuadori San Juanito (Szent János tánc). A bolíviai bányavidéken ma is népszerú diablada (ördögös tánc) során maskarás táncosok Szent Mihály és Szupaj (ördög) harcát elevenítik fel. (Európai szemlélố számára egyik jelmez sem emlékeztet sem ördögre, sem szentre.) A küzdelmet a Tárnák Csodatévó Színe dönti el Szent Mihály javára.

Az indián és a mesztic zene mellett él az Andokban afro-latin és kreol muzsika is. Afro eredetú indián zene a saya, vagy más néven tundiki.

Tipikus kreol táncok a bolíviai bailecito és a cueca. Mindkettố páros tánc, fehér öltönyben és estélyi ruhában, zsebkendôvel a kézben illik járni. A cueca egyik változata, a zamacueca Peruban marinera néven az ország nemzeti tánca lett. Ezek természetesen valamennyien távol állnak a népzenétôl.

Dél-Amerika egyes területein annyira eleven a folklór, hogy még ma is születnek népdalok, népi táncok. Jó példa erre a doctorcito nevú tánc, amely egy ôsi indián ritmus, a cullahua új változataként, a századfordulón keletkezett. A tánc egy legendás, Bolívia-szerte ismert vándor mesztic orvos emlékét idézi fel. A táncot színes poncsóban, cilinderrel és esernyôvel járják. 